\title{
VÄLITTÖMÄSTI YHDESSÄ
}

\section{- PUHEENVUOROJA AIKUISOPISKELUSTA JA TUTKIMUKSESTA}

AIKUISKASVATUKSEN TUTKIMUSSEURAN juhlavuoden innoittamana vietettiin Lapin maakuntakirjastolla seuran 70. juhlavuotta tieteen ja taiteen voimin 18.9.2010. Kaikille avoimen tapahtuman paikaksi oli valittu kirjasto, joka toimii kaupunkilaisten olohuoneena, sinne on helppo tulla. Tapahtumassa vuorottelivat kavalkadimaisesti opiskelijoiden, ohjaajien ja tutkijoiden puheenvuorot. Tapahtuman järjestäjinä toimivat tutkimusseuran lisäksi Lapin yliopisto, Rovala-Opisto, Rovaniemen kansalaisopisto, Lapin maakuntakirjasto ja Kansalaisfoorumi.

Päivän teemana oli yhteisöllisyys: aikuiskasvatuksen kentän ohjaajien ja opiskelijoiden sekä tutkimuksen äänten kohtauttaminen. Esityksistä jäsentyivät teemat: sukupolvien ja kulttuurien kohtaaminen arjessa sekä yhteisöllisyys ja yhteiskunnan muutos. Helena Koskinen kertoi tutkimuksestaan, jossa tarkastellaan perhesukupolvien välisiä kohtaamisia oppimiskokemuksina. Samaan teemaan yhdistyi saamelaismuusikko Jaakko Gauriloff pohdinta perinteisen kulttuuritiedon välittymisestä. Hän totesi, ettei estraditaide riitä, tarvittaisiin arjen kohtaamisia sukupolvien välillä. Kielitaidon merkitystä kulttuuriin kiinnittymiselle korostivat suomenkieltä opiskeleva Stefanie Lavan ja vieraita kieliä opiskeleva Aino Korhonen.
Jaakko Gauriloff toi esille, että irtaantuminen yhteisöstä, esimerkiksi muutto etäälle perinteen taitajista, estää tiedonjakamista arjen kohtaamisissa. Helena Koskisen tutkimus vahvistaa saman. Kulttuurinen tieto on traditionaalista ja ajankohtaista, ja sen välittyminen sukupolvien välisissä kohtaamisissa on monipuolista ja merkityksellistä. Tässä vuorovaikutuksessa välittyy traditionaalista tietoa, joka on sidoksissa tapoihin, kansanperinteeseen, uskomuksiin ja myytteihin ja ajankohtaista informaatiota, joka tulee käyttöön päätöksenteossa ja auttaa selviytymään päivittäisissä tilanteissa. Tällainen ad hoc-mentoring siirtää tietoa, joka perustuu hiljaiselle tiedolle, kokemukselle ja rutiineille. Merkityksellistä on myös arvo-, normi- ja odotusperustainen tieto. Puhuttaessa sukupolvista ja oppimisesta, eivät ainoastaan joko vanhemmat tai nuoremmat ole niitä, jotka tietävät ja siirtävät tietoa, vaan vuorovaikutus tulee ymmärtää tasavertaisena, kahdensuuntaisena kommunikaationa.(Koskinen 2008.)

\section{RYHMÄSSÄ VOIMAANTUMINEN}

Työelämään liittyvä tutkimuspuheenvuoro kuultiin Outi Ylitapio-Mäntylän kertomana. Hänen esityksensä aiheena oli Muisteleminen työnohjauksellista 
kerrontaa. Puheenvuoro pohjautui väitöstutkimukseen, jossa aineisto on kerätty muistelutyömenetelmää soveltaen. Muistelijoina olivat lastentarhanopettajat (Ylitapio-Mäntylä 2009). Muistelutyöskentelyn luonne työskentelymuotona virittää osallistujia keskustelemaan ja jakamaan kokemuksiaan työstä ja pohtimaan työhön liittyviä ongelmia ja pulmia, joita pohditaan työnohjauksessa. Menetelmä tarjoaa osallistujille puhumisen tilan, mahdollisuuden pysähtyä keskustelemaan ja jakamaan asioita. Kuitenkaan sen alkuperäinen tavoite ei ole ongelmien tuominen ryhmään, vaan muistelu jostakin valitusta teemasta ja muistojen tarkastelu nykyhetkessä kuten omassa työssä, opetuksessa ja kasvatuksessa.

Työnohjauksellisuus kuului erityisesti niissä puheissa, joissa lastentarhanopettajat pohtivat jaksamistaan, työhön turhautumista ja riittämättömyyden tunnetta. Ryhmä oli ikään kuin pysähtymisen paikka työnkiireiden jälkeen. Kokemusten jakaminen ja toisten tarinoiden kuunteleminen auttoi ymmärtämään omaa toimintaa työs-

sään. Ryhmäkeskustelut olivat myös konkreettista avun antamista johonkin kasvatukselliseen ongelmaan. Ryhmätyöskentely on toisen kohtaamista ja voimaantumisen kokemisen mahdollisuutta. (Ylitapio-Mäntylä 2009.)

Ryhmässä toimimisen voimaannuttava kokemus tuli esille kahdessa kansalaisopiston opintoryhmäläisen puheenvuoroissa. Mikko Vehkaperä kertoi Seitakuoron laulajana kuoroon kuulumisen ja kuorolaulun merkityksistä laulajalle. Hänelle kuorolauluun liittyvä omaehtoinen opiskelu on jatkuva ja haastava oppimisprosessi, joka on jatkunut lapsuudesta saakka. Juha Imberg kertoi teatteriryhmän Saalot ryhmään liittymisestään ja näyttelemisen merkityksestä itselleen. Teatteriryhmän ohjaaja Sari Laatikainen kertoi valinneensa näytelmien aiheet Rovaniemen paikallishistoriasta. Iltapäivän aikana nähtiin kohtaus "Mainen kunniat" näytelmästä, joka käsitteli sota-aikaa avaten kulttuurista tietoisuutta sota-ajasta nykyaikaan.

\section{KANSALAISESTA MINÄN BRÄNDÄYKSEEN}

Seija Keskitalo-Foley analysoi tutkimuspuheenvuorossaan kasvatusihanteita keskittyen nykyisen koulutuspolitiikan käsitteeseen, yrittäjämäisyyteen. Kullakin aikakaudella luodaan omat kasvatusihanteet ja "hyvän ihmisen” ideaalit. Leena Kosken (2001) mukaan viime vuosisadan alussa ajateltiin, että sivistystä lisäämällä kansakuntien elämä edistyy, valtiot vaurastuvat ja yksilöiden elämä tulee rikkaaksi ja syvälliseksi. Tähän ajatteluun liittyvät keskeisesti luterilais-kansallisen kasvatusmoraalin hyveet kuten isänmaallisuus, raittius, nöyryys, kuuliaisuus, kiltteys, siisteys, rehellisyys ja urhoollisuus.

Kun viime vuosisadalla kasvatusihanteisiin liittyi jollain tavalla yhteisöllisyys, nykyinen kasvatus- ja koulutuspolitiikka korostaa yksilöllisyyttä. Yrittäjyyskasvatuksen avulla lanseerattu uudenlainen ihmis- ja kansalaisideaali, joka edellyttää itsen tuotteistamista ja markkinoimista. Muutosta on tulkittu individualistisena käänteenä ja uusliberalistisena politiikkana, joiden seurauksena riskien ja vastuun siirtäminen yksilöiden harteille on koskenut niin työelämää kuin koulutustakin. Kun aiemmin työmarkkinakelpoisuuden ytimeksi riitti ammattitaito, nyky-yhteiskunnassa huomio on siirtynyt yksilön persoonallisuuteen. Uusliberalismin markkinamuotoisuuden, suorituskeskeisyyden sekä erinomaisuuden eetos tuottaa yksilöille jatkuvan brändäyksen - muista erottautumisen - vaatimuksen. Kasvatus- ja koulutuspolitiikan muutosta ei nähdä ideologisena ja poliittisena, vaan yrittäjäminuus on luonnollistumassa osaksi koulutusdiskurssia. Tutkimuksen avulla voimme kuitenkin analysoida kasvatuksen ja koulutuksen merkitystä kasvatusihanteiden tuottajana ja muokkaajana. (Keskitalo-Foley, Komulainen \& Naskali 2010.)

\section{LOPUKSI}

Välittömästi yhdessä tapahtuma avasi välähdyksiä aikuisopiskeluun ja -tutkimukseen. Opiskelijoiden, oh- 
jaajien ja tutkijoiden kohtaaminen on merkityksellistä ja voimaannuttavaa. Eri toimijoiden kohtaaminen saa ajatuksia liikkeelle, herättää tunteita ja välittää tunnelmia. Yhdessä tekeminen on toisen kuulemista ja nä- kemistä, taitojen ja tietojen jakamista, kokemusten ja osaamisen vaihtamista. Elävää vuorovaikutusta ja yhdessä oloa sekä erilaisten osaamisten näkyväksi tekemistä tarvitaan, sillä yhdessä on enemmän kuin yksin.

\section{LÄHTEET}

Keskitalo-Foley, S., Komulainen, K. \& Naskali, P. (2010). Risto Reipas riskinottaja. Koulutuspolitiikan tavoittelema ihannekansalainen. Teoksessa K. Komulainen, S. Keskitalo-Foley, M. Korhonen \& S. Lappalainen (toim.) Yrittäjyyskasvatus hallintana. Tampere: Vastapaino, 15-36

Koski, L. (2001). Hyvän lapsen ja kasvattamisen ideaalit - Tutkimus aapisten ja lukukirjojen moraalisen kosmologian muutoksista itsenäisyyden aikana. Turku: Suomen Kasvatustieteellinen Seura. Koskinen, H. (2008). Perhesukupolvien väliset kohtaamiset arjen oppimiskokemuksina. teoksessa
Aikuiskasvatus kevytyhteisöjen ajassa. S. Poikela \& O. Ylitapio-Mäntylä (toim.) Lapin yliopistokustannus: Rovaniemi. Verkkojulkaisu: http://www.ulapland.fi/ includes/file_download.asp?DeptID=7311\&fileid=146 $84 \&$ file=20081210151651.pdf\&pdf=1 , 61-72.

Ylitapio-Mäntylä, O. (2009). Lastentarhanopettajien jaettuja muisteluja sukupuolesta ja vallasta arjen käytännöissä. Acta Universitatis Lapponiensis 171. Rovaniemi: Lapin yliopistokustannus. 